\title{
Safety Assurance for Challenging Geotechnical Civil Engineering Constructions in Urban Areas
}

\author{
Rolf Katzenbach, Christiane Bergmann, Steffen Leppla \\ Technische Universität Darmstadt, Institute and Laboratory of Geotechnics, Germany \\ Email: katzenbach@geotechnik.tu-darmstadt.de
}

Received July 2013

\begin{abstract}
Safety is the most important aspect during design, construction and service time of any structure, especially for challenging projects like high-rise buildings and tunnels in urban areas. A high level design considering the soil-structureinteraction, based on a qualified soil investigation is required for a safe and optimised design. Due to the complexity of geotechnical constructions the safety assurance guaranteed by the 4-eye-principle is essential. The 4-eye-principle consists of an independent peer review by publicly certified experts combined with the observational method. The paper presents the fundamental aspects of safety assurance by the 4-eye-principle. The application is explained on several examples, as deep excavations, complex foundation systems for high-rise buildings and tunnel constructions in urban areas. The experiences made in the planning, design and construction phases are explained and for new inner urban projects recommendations are given.
\end{abstract}

Keywords: Natural Asset; Financial Value; Neural Network

\section{Introduction}

A safety design and construction of challenging projects in urban areas is based on the following main aspects:

- qualified experts for planning, design and construction;

- interaction between architects, structural engineers and geotechnical engineers;

- adequate soil investigation;

- design of deep foundation systems using the FiniteElement-Method (FEM) in combination with enhanced in-situ load tests for calibrating the soil parameters used in the numerical simulations;

- quality assurance by an independent peer review process and the observational method (4-eye-principle).

These facts will be explained by large construction projects which are located in difficult soil and groundwater conditions.

\section{The 4-Eye-Principle}

The basis for safety assurance is the 4-eye-principle. This 4-eye-principle is a process of an independent peer review as shown in Figure 1. It consists of 3 parts. The investor, the experts for planning and design and the construction company belong to the first division. Planning and design are done according to the requirements of the investor and all relevant documents to obtain the building permission are prepared. The building authorities are the second part and are responsible for the building permission which is given to the investor. The third division consists of the publicly certified experts. They are appointed by the building authorities but work as independent experts. They are responsible for the technical supervision of the planning, design and the construction.

In order to achieve the license as a publicly certified expert for geotechnical engineering by the building authorities intensive studies of geotechnical engineering in university and large experiences in geotechnical engineering with special knowledge about the soil-structureinteraction have to be proven.

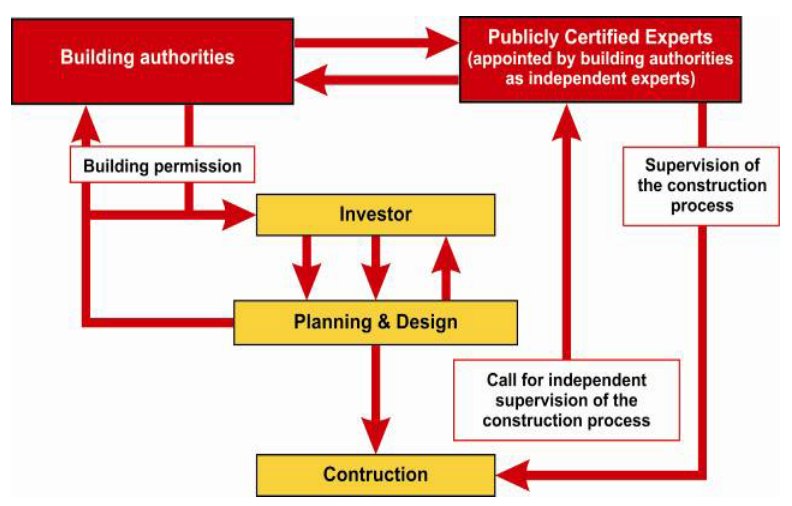

Figure 1. Independent peer review process. 
The independent peer review by publicly certified experts for geotechnical engineering makes sure that all information including the results of the soil investigation consisting of laboratory and field tests and the boundary conditions defined for the geotechnical design are complete and correct.

In the case of a defect or collapse the publicly certified expert for geotechnical engineering can be involved as an independent expert to find out the reasons for the defect or damage and to develop a concept for stabilization and reconstruction [1].

For all difficult projects an independent peer review is essential for the successful realization of the project.

\section{Observational Method}

The observational method is practical to projects with difficult boundary conditions for verification of the design during the construction time and, if necessary, during service time. For example in the European Standard Eurocode 7 (EC 7) the effect and the boundary conditions of the observational method are defined.

The application of the observational method is recommended for the following types of construction projects [2]:

- very complicated/complex projects;

- projects with a distinctive soil-structure-interaction, e.g. mixed shallow and deep foundations, retaining walls for deep excavations, Combined Pile-Raft Foundations (CPRFs);

- projects with a high and variable water pressure;

- complex interaction situations consisting of ground, excavation and neighbouring buildings and structures;

- projects with pore-water pressures reducing the stability;

- projects on slopes.

The observational method is always a combination of the common geotechnical investigations before and during the construction phase together with the theoretical modeling and a plan of contingency actions (Figure 2). Only monitoring to ensure the stability and the service ability of the structure is not sufficient and, according to the standardization, not permitted for this purpose.

Overall the observational method is an institutionalized controlling instrument to verify the soil and rock mechanical modeling $[3,4]$.

The identification of all potential failure mechanisms is essential for defining the measure concept. The concept has to be designed in that way that all these mechanisms can be observed. The measurements need to be of an adequate accuracy to allow the identification of critical tendencies. The required accuracy as well as the boundary values need to be identified within the design phase of the observational method.

Contingency actions needs to be planned in the design phase of the observational method and depend on the ductility of the systems.

The observational method must not be seen as a potential alternative for a comprehensive soil investigation campaign. A comprehensive soil investigation campaign is in any way of essential importance. Additionally the observational method is a tool of quality assurance and allows the verification of the parameters and calculations applied in the design phase. The observational method helps to achieve an economic and save construction [5].

\section{In-Situ Load Test}

On project and site related soil investigations with core drillings and laboratory tests the soil parameters are determined. Laboratory tests are important and essential for the initial definition of soil mechanical properties of the

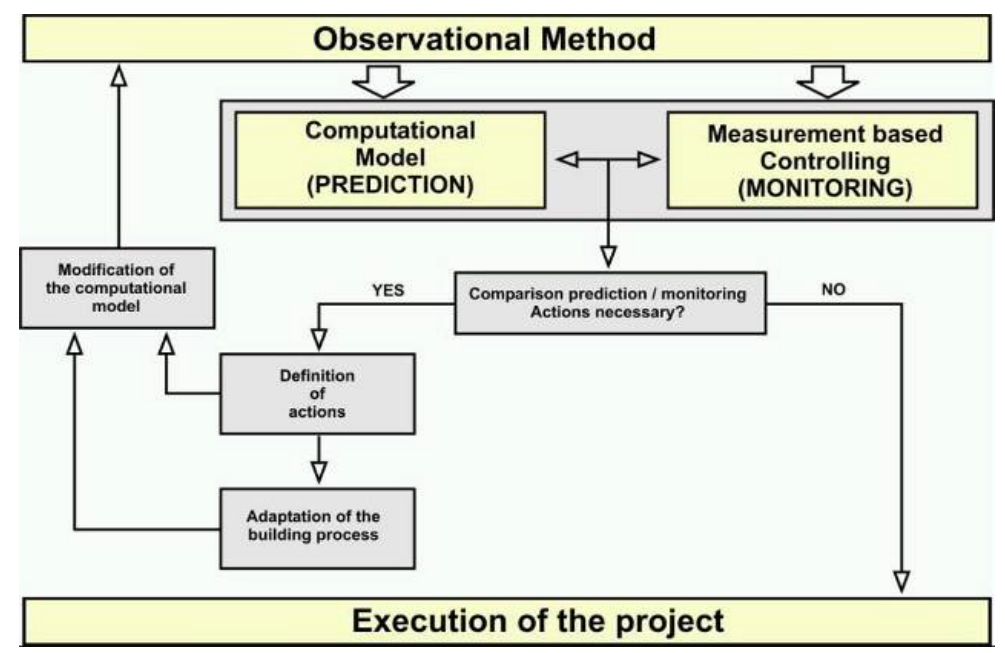

Figure 2. Observational method. 
soil layer, but usually not sufficient for an entire and realistic capture of the complex conditions, caused by the interaction of subsoil and construction [6].

In order to reliably determine the ultimate bearing capacity of piles, load tests need to be carried out [7]. For pile load tests often very high counter weights or strong anchor systems are necessary. By using the Osterberg method high loads can be reached without installing anchors or counter weights. Hydraulic jacks induce the load in the pile using the pile itself partly as abutment. The results of the field tests allow a calibration of the numerical simulations.

The principle scheme of pile load tests is shown in Figure 3.

\section{Examples for Engineering Practice}

\subsection{Classic Pile Foundation for a High-Rise Building in Frankfurt Clay and Limestone}

In the downtown of Frankfurt am Main, Germany, on a construction site of $17,400 \mathrm{~m}^{2}$ the high-rise building project "PalaisQuartier" has been realized (Figure 4). The construction was finished in 2010.

The complex consists of several structures with a total of $180,000 \mathrm{~m}^{2}$ floor space, thereof $60,000 \mathrm{~m}^{2}$ underground (Figure 5). The project includes the historic building “Thurn-und Taxis-Palais" whose façade has been preserved (Unit A). The office building (Unit B), which is the highest building of the project with a height of $136 \mathrm{~m}$ has 34 floors each with a floor space of $1340 \mathrm{~m}^{2}$. The hotel building (Unit C) has a height of $99 \mathrm{~m}$ with 24 upper floors. The retail area (Unit D) runs along the total length of the eastern part of the site and consists of eight upper floors with a total height of $43 \mathrm{~m}$.

The underground parking garage with five floors spans across the complete project area. With an $8 \mathrm{~m}$ high first sublevel, partially with mezzanine floor, and four more

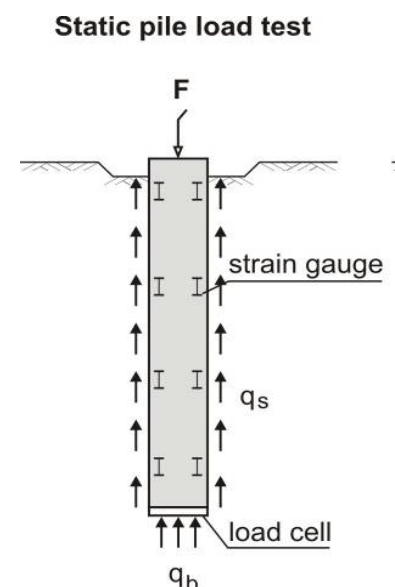

$$
\begin{gathered}
\text { Pile load test with } \\
\text { jack and segmented pile }
\end{gathered}
$$

Figure 3. Principle scheme of pile load tests.

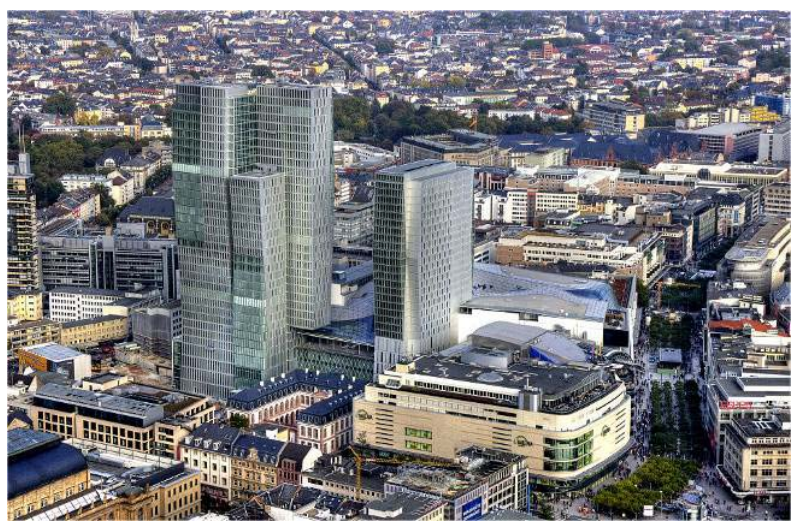

Figure 4. “PalaisQuartier”, Frankfurt am Main, Germany.

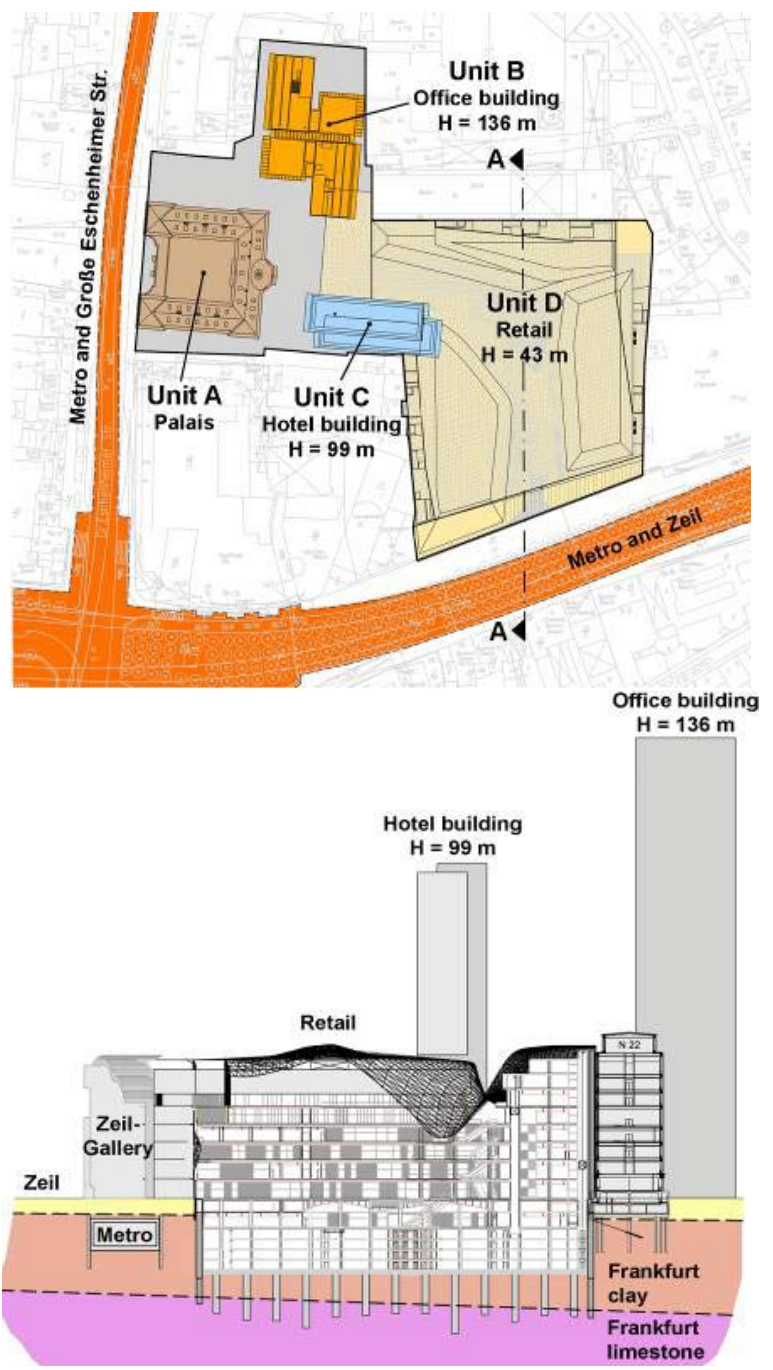

Figure 5. “PalaisQuartier”, Frankfurt am Main, Germany: plan view (top) and cross section A-A (bottom).

sub-levels the foundation depth results to $22 \mathrm{~m}$ below ground level. Thereby excavation bottom is at $80 \mathrm{~m}$ above sea level (msl). A total of 302 foundation piles (diameter up to $1.86 \mathrm{~m}$, length up to $27 \mathrm{~m}$ ) reach down to 
depths of $53.2 \mathrm{~m}$ to $70.1 \mathrm{~m}$. above sea level depending on the structural requirements.

The pile head of the 543 retaining wall piles (diameter $1.5 \mathrm{~m}$, length up to $38 \mathrm{~m}$ ) were located between $94.1 \mathrm{~m}$ and $99.6 \mathrm{~m}$ above sea level, the pile base was between $59.8 \mathrm{~m}$ and $73.4 \mathrm{~m}$ above sea level depending on the structural requirements. As shown in the sectional view (Figure 6), the upper part of the piles is in the Frankfurt Clay and the base of the piles is set in the rocky Frankfurt Limestone.

Regarding the large number of piles and the high pile loads a pile load test has been carried out for optimization of the classic pile foundation. Osterberg-Cells (O-Cells) have been installed in two levels in order to assess the influence of pile shaft grouting on the limit skin friction of the piles in the Frankfurt Limestone (Figure 6). The test pile with a total length of $12.9 \mathrm{~m}$ and a diameter of $1.68 \mathrm{~m}$ consist of three segments and has been installed in the Frankfurt Limestone layer $31.7 \mathrm{~m}$ below ground level. The upper pile segment above the upper cell level and the middle pile segment between the two cell levels can be tested independently. In the first

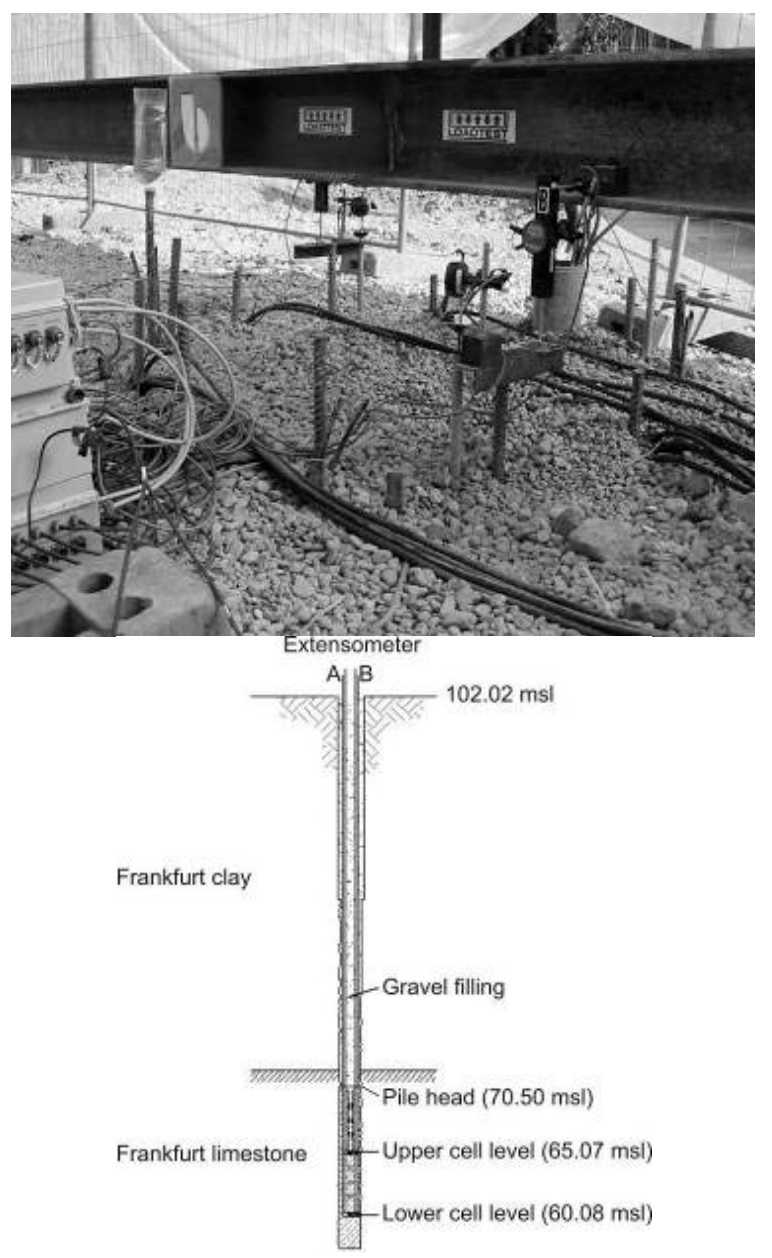

Figure 6. Pile load test setup. phase of the test the upper part was loaded by using the middle and the lower part as abutment. A limit of $24 \mathrm{MN}$ could be reached (Figure 7). The upper segment was lifted about $1.5 \mathrm{~cm}$, the settlement of the middle and lower part was $1.0 \mathrm{~cm}$. The mobilized shaft friction was about $830 \mathrm{kN} / \mathrm{m}^{2}$.

Subsequently the upper pile segment was uncoupled by discharging the upper cell level. In the second test phase the middle pile segment was loaded by using the lower segment as abutment. The limit load of the middle segment with shaft grouting was 27.5 MN (Figure 7). The skin friction was $1040 \mathrm{kN} / \mathrm{m}^{2}$, this means $24 \%$ higher than without shaft grouting. Based on the results of the pile load test using O-Cells the majority of the 290 foundation piles were made by applying shaft grouting. Due to pile load test the total length of was reduced significantly.

\subsection{CPRF for a High-Rise Building in Clay Marl}

In the scope of the project Mirax Plaza in Kiev, Ukraine, 2 high-rise buildings, each of them $192 \mathrm{~m}$ (46 storeys) high, a shopping and entertainment mall and an underground parking are under construction (Figure 8). The
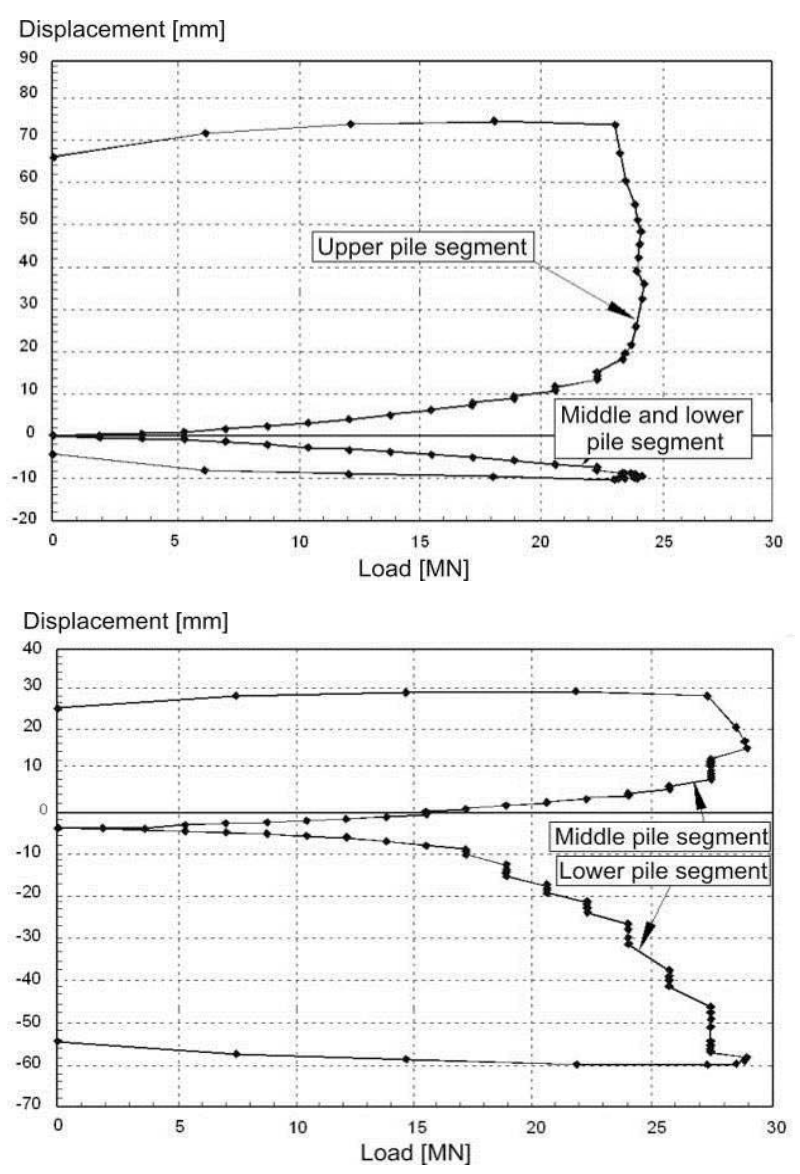

Figure 7. Load displacement curve of test phase 1 (top) and test phase 2 (bottom). 
area of the project is about $294,000 \mathrm{~m}^{2}$ and cuts a $30 \mathrm{~m}$ high natural slope.

The geotechnical investigations have been executed 70 $\mathrm{m}$ deep. The soil conditions at the construction site are as follows:

- fill to a depth of $2 \mathrm{~m}$ to $3 \mathrm{~m}$

- quaternary silty sand and sandy silt with a thickness of $5 \mathrm{~m}$ to $10 \mathrm{~m}$

- tertiary silt and sand (Charkow and Poltaw formation) with a thickness of $0 \mathrm{~m}$ to $24 \mathrm{~m}$

- tertiary clayey silt and clay marl of the Kiev and Butschak formation with a thickness of about $20 \mathrm{~m}$

- tertiary fine sand of the Butschak formation up to the investigation depth

The ground water level is in a depth of about $2 \mathrm{~m}$ below the ground surface. The soil conditions and a cross section of the project are shown in Figure 9.

For verification of the shaft and base resistance of the deep foundation elements and for calibration of the numerical simulations pile load tests have been carried out on the construction yard. The piles had a diameter of $0.82 \mathrm{~m}$ and a length of about $10 \mathrm{~m}$ to $44 \mathrm{~m}$. Using the results of the load tests the back analysis for verification of the FEM simulations was done. The soil properties in accordance with the results of the back analysis were partly 3 times higher than indicated in the geotechnical report. Figure 10 shows the results of the load test No. 2 and the numerical back analysis. Measurement and calculation show a good accordance.

The obtained results of the pile load tests and of the executed back analysis were applied in 3-dimensional FEM-simulations of the foundation for Tower A, taking advantage of the symmetry of the footprint of the building. The overall load of the Tower A is about $2200 \mathrm{MN}$ and the area of the foundation about $2000 \mathrm{~m}^{2}$ (Figure 11).

The foundation design considers a CPRF with 64 barrettes with $33 \mathrm{~m}$ length and a cross section of $2.8 \mathrm{~m} \times 0.8$ $\mathrm{m}$. The raft of $3 \mathrm{~m}$ thickness is located in Kiev Clay Marl at about $10 \mathrm{~m}$ depth below the ground surface. The barrettes are penetrating the layer of Kiev Clay Marl reaching the Butschak Sands.

The calculated loads on the barrettes were in the range of 22.1 MN to 44.5 MN. The load on the outer barrettes was about 41.2 MN to 44.5 MN which significantly exceeds the loads on the inner barrettes with the maximum value of 30.7 MN. This behavior is typical for a CPRF. The outer deep foundation elements take more loads because of their higher stiffness due to the higher
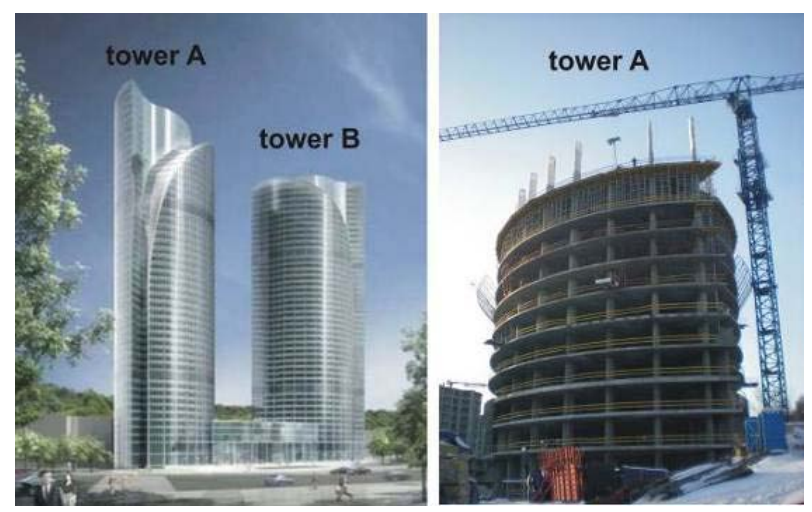

Figure 8. Mirax Plaza Kiev: animation tower A and B (left), tower $\mathrm{A}$ under construction (right).

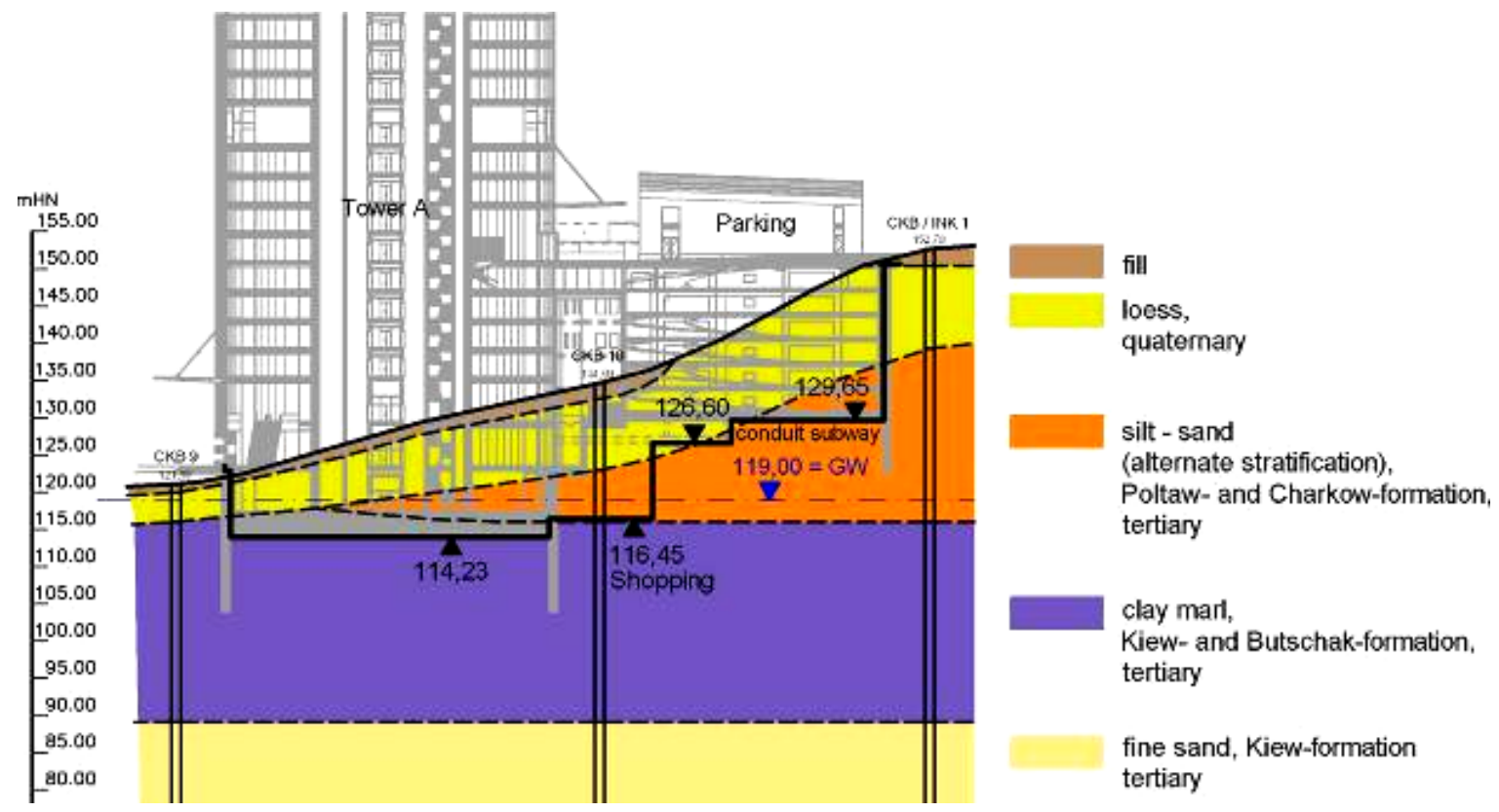

Figure 9. Soil conditions and cross section of the project area. 


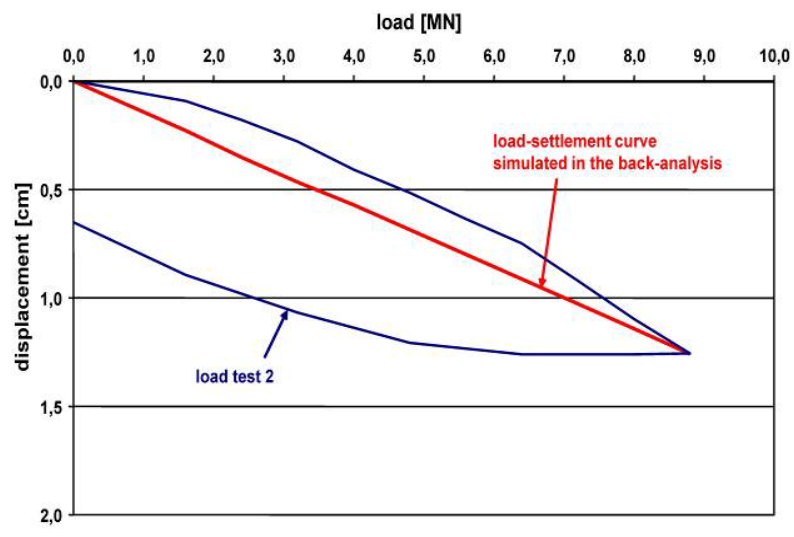

Figure 10. Results of the in-situ load test and the numerical simulations.

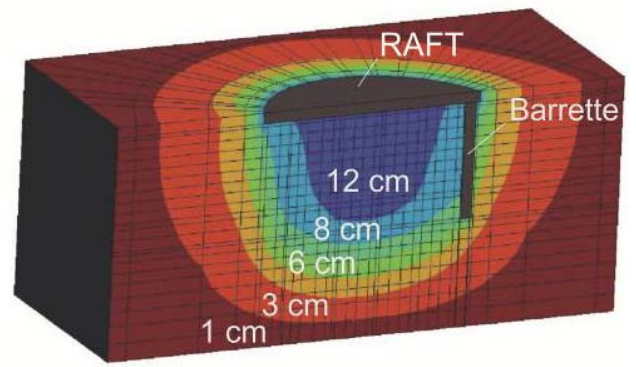

Figure 11. FEM-model of the CPRF of Tower A and calculated settlements in [cm].

volume of the activated soil. The CPRF coefficient is $\alpha_{\mathrm{CPRF}}=0.88$. Maximum settlements of about $12 \mathrm{~cm}$ were calculated due to the settlement-relevant load of $85 \%$ of the total design load. The pressure under the foundation raft is calculated in the most areas not exceeding 200 $\mathrm{kN} / \mathrm{m}^{2}$, at the raft edge the pressure reaches $400 \mathrm{kN} / \mathrm{m}^{2}$. The calculated base pressure of the outer barrettes has an average of $5100 \mathrm{kN} / \mathrm{m}^{2}$ and for inner barrettes an average of $4130 \mathrm{kN} / \mathrm{m}^{2}$. The mobilized shaft resistance increases with the depth reaching $180 \mathrm{kN} / \mathrm{m}^{2}$ for outer barrettes and $150 \mathrm{kN} / \mathrm{m}^{2}$ for inner barrettes.

During the construction of Mirax Plaza the observational method according to EC 7 is applied. Especially the distribution of the loads between the barrettes and the raft is monitored. For this reason 3 earth pressure devices were installed under the raft and 2 barrettes (most loaded outer barrette and average loaded inner barrette) were instrumented over the length.

In the scope of the project Mirax Plaza the new allowable shaft resistance and base resistance were defined for typical soil layers in Kiev. This unique experience will be used for the skyscrapers of new generation in Ukraine.

The CPRF of the high-rise building project Mirax Plaza represents the first authorized CPRF in the Ukraine. Using the advanced optimization approaches and taking advantage of the positive effect of CPRF the number of barrettes could be reduced from 120 barrettes with $40 \mathrm{~m}$ length to 64 barrettes with $33 \mathrm{~m}$ length. The foundation optimization leads to considerable decrease of the utilized resources (cement, aggregates, water, energy etc.) and cost savings of about 3.3 Million US\$.

\section{REFERENCES}

[1] R. Katzenbach, S. Leppla, A. Weidle and D. Choudhury, "Aspects Regarding Management of Soil Risk," 4th International Seminar on Forensic Geotechnical Engineering, Bengaluru, 10-12 January 2013, p. 12.

[2] R. Katzenbach, A. Weidle and S. Kurze, "Baugrund und Grundwasser Erkundungsproblematik, Baugrundrisiko und Technische Risiken,” 39. Baurechtstagung der Arge Baurecht des Deutschen Anwaltsvereins, Berlin, 16-17 March 2012, p. 22.

[3] W. Rodatz, J. Gattermann and T. Bergs, "Results of Five Monitoring Networks to Measure Loads and Deformations at Different Quay Wall Constructions in the Port of Hamburg," 5th International Symposium on Field Measurements in Geomechanics, Singapore, 1-3 December 1999, p. 4.

[4] R. Katzenbach, A. Schmitt and J. Turek, "Co-Operation between the Geotechnical and Structural EngineersExperiences from Projects in Frankfurt," COST Action C7, Soil-Structure-Interaction in Urban Civil Engineering, Thessaloniki, 1-2 October 1999, pp. 53-65.

[5] R. Katzenbach, G. Bachmann, S. Leppla and H. Ramm, "Chances and Limitations of the Observational Method in Geotechnical Monitoring,” 14th Danube-European Conference on Geotechnical Engineering, Bratislava, 2-4 June 2010, p. 13.

[6] R. Katzenbach, “Optimised Design of High-Rise Building Foundations in Settlement-Sensitive Soils,” International Geotechnical Conference of Soil-Structure-Interaction, St. Petersburg, 26-28 May 2005, pp. 39-46.

[7] J.-L. Briaud, M. Ballouz and G. Nasr, "Static Capacity Prediction by Dynamic Methods for Three Bored Piles," Journal of Geotechnical and Geoenvironmental Engineering, Vol. 126, ASCE, Reston, Virginia, USA, July 2000, pp. 640-649. 